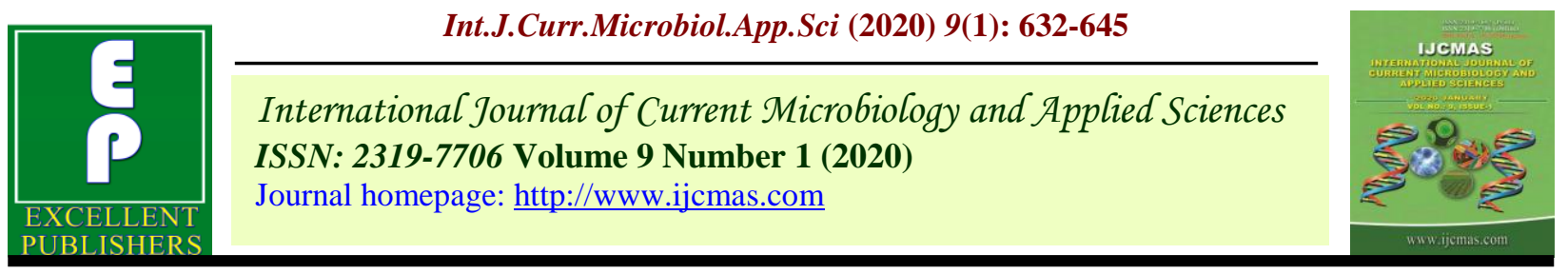

Original Research Article

https://doi.org/10.20546/ijcmas.2020.901.069

\title{
Appraisement of Total Organic Carbon under Different Levels of +Nitrogen in Different Size Soil Aggregates in Cereal-Pulse Based Cropping System in Rained Condition
}

\author{
Ushakumari* and A. Sathish \\ Soil Science and Agricultural Chemistry, UAS, GKVK, Bengaluru, India \\ *Corresponding author
}

Keywords

Nitrogen level, Crop type, available nutrient status, rainfed, TOC.

\section{Article Info}

Accepted:

15 December 2019

Available Online:

20 January 2020
A B S T R A C T

The effect of increasing levels of nitrogen on organic carbon and nutrient status under finger millet, maize and field bean, cultivated soil was studied in the experiment. Experiment was conducted at AICRPDA, under rainfed condition. Split plot design was used which consist of three levels of nitrogen viz., high (100\% Recommended dose $\mathrm{RD}$ ), medium (50\% RD) and low (no application of nitrogen) as subplot and type of crop grown as finger millet, field bean and maize were grown as main plot under rainfed condition. Apart from nitrogen, other cultural practices were followed as per the package of practices. Soil samples were separated in to two size aggregates, macro $(>250 \mu \mathrm{m})$ and micro $(>250 \mu \mathrm{m})$ using wet sieving method. Total organic carbon (TOC) was analysed in each group of aggregates under cultivation of field bean, finger millet and maize separately and available nutrients of soil were analysed and recorded after the harvesting of crop. It was found that increased level of nitrogenous fertilizer enhanced the total organic carbon in all the crops and impact was more pronounced under maize (cereal crop). Macro aggregates recorded with higher accumulation of TOC as compared to micro aggregates. Available nitrogen and micronutrients were recorded in increasing trend with increase in the nitrogen level. Available phosphorus and potassium content in soil a decreased in content with increasing the levels of nitrogen. The interaction effect of crop grown and level of nitrogen was recorded non-significant under available nutrients content in rainfed condition. The Thus, it was concluded that higher nitrogen level increased the TOC as well as maintained the soil nutrient status in the soil as compared to low level. Cultivation of different crops has differential impact on soil nutrient status and plays an important role in the soil fertility. 


\section{Introduction}

Cereal-pulse based cropping system is one of the most adopted types of cropping system among the farmers of Karnataka. Finger millet, field bean and maize are among the major crops grown in the state under cereal pulse based cropping system. The cultivation of these crops affects the soil nutrient status differentially. Field bean being the nitrogen fixing crop improves the fertility of the soil in long term. Finger millet is the staple crop of Karnataka state and included in dietary routine along with maize. Finger millet in Karnataka occupies about 1 million ha area with production of 1.8 million tons. It is cultivated on varied soils and climatic conditions owing to wider adaptability and tolerance to stress situations. Similarly, Karnataka contributes in field bean nearly $90 \%$ of area and production in the country (Sultan Singh et al., 2010). It is grown annually in an area of 79,462 ha $(66,976$ ha in Kharif and 12,486 in Rabi / summer) with a production of 68014 tons (64,215 in Kharif and 3,799 tonnes Rabi / summer) in Karnataka (Anon., 2010). India produces about $2 \%$ the world's maize produce. Karnataka is the leading producer of maize in India producing around $16 \%$ of India's total Maize production. Normal area under maize cultivation is 11.3 lakh in Karnataka and accounted highest production compared to whole of India (Anon., 2017).

The crop growth is mainly governed by the nutritional status, specifically nitrogen as it is a structural constituent of plant cell and constitutes amino acids, proteins, nucleic is acids, etc. Nitrogen is normally a key factor in achieving optimum grain yields (Fageria et al., 1997). It is, however, one of the most expensive inputs and if used improperly, can pollute the ground water. Combined with low soil fertility, low nitrogen rates as a risk management strategy might contribute to nitrogen deficiency (Monjardino et al., 2013; Monjardino et al., 2015). The different level of nitrogen affects the yield as well soil nutrient status and it imparts its effect differentially among crop types.

Soil aggregation immensely effect on carbonnitrogen dynamics. The possible mechanism of aggregates interaction (macro and micro aggregates) with dynamics/ kinetics of soil organic carbon-nitrogen is the confinement of plant debris or decomposed organic matter $(\mathrm{OM})$ inside the micro aggregates and forming a stable macro aggregates by occluded of old organic $\mathrm{C}$ in micro aggregates as binding agent (Blanco-Canqui and Lal, 2004). Soil aggregates in various size groups is a major accumulator of organic matter (Elliott and Coleman, 1988). The deets on total organic carbon in various sized soil aggregates is very crucial as it facilitate to quantify the content of $(\mathrm{OM})$ organic matter, which can be potentially conserved in soil, which in turn affects soil structure (Kadlec et al., 2012). Keeping these points in view, the study has been carried out to see the effect of different level of nitrogen on TOC under finger millet, field bean and maize cultivation and their interactive effect on soil available nutrients.

\section{Materials and Methods}

The present study was conducted in two different experimental plots, one under rainfed condition at AICRPDA and another irrigated at AICRP on Agroforestry, GKVK, UAS, Bengaluru during the season 2016-2017. The experimental field has been divided according to the split plot design into 36 plots which have three main treatments as cropping system which includes finger millet, field bean and maize crops. This main plots are further divided into three sub-plots which represents three levels of nitrogen high, medium and low and details of these treatments is mentioned in 
the table below. The cultivation practices followed as per the package and practices of UAS, Bengaluru prescribed for the above mentioned crops apart from the nitrogen application. The experimental details are:

Location: AICRPDA and AICRP on Agroforestry, Bengaluru

Crop: Finger millet, Maize, Field Bean/Lablab Statistical Design: Split Plot Number of Treatments: $\quad 9$ Number of Replications: $\quad 4$ Season: $\quad$ Kharif 2017
Treatment details:

Three main plot treatments consist of cultivation of crops like maize, finger millet and field bean which are further divided into three subplots representing low dose of nitrogen that implies zero amount of nitrogen was applied, medium implies that $50 \%$ of the recommended dose of nitrogen had applied and high level which consist of $100 \%$ of recommended dose of nitrogen was applied. All other nutrients were applied as per the recommended doses of that particular crop. This set of experiment was conducted in this manner at both irrigated and rainfed condition at the respective selected fields.

\begin{tabular}{|c|c|c|c|c|}
\hline & & Mains plot & Sub plot & $\begin{array}{l}\text { Total } \\
\text { dimension }\end{array}$ \\
\hline \multirow[t]{2}{*}{ Rainfed } & $\begin{array}{l}\text { Plot size } \\
\text { (sq.m) }\end{array}$ & $12 \times 18$ & $6 \times 6$ & $60 \times 54$ \\
\hline & Spacing(cm) & $\begin{array}{l}13.5 \times 9 \text { Finger } \\
\text { millet }\end{array}$ & $\begin{array}{l}30 \times 30 \\
\text { Maize }\end{array}$ & $\begin{array}{l}45 \times 15 \\
\text { Field } \\
\text { bean/lablab }\end{array}$ \\
\hline \multirow[t]{2}{*}{$\begin{array}{l}\text { Irrigate } \\
\text { d }\end{array}$} & $\begin{array}{l}\text { Plot size (sq. } \\
\text { m) }\end{array}$ & $18 \times 30$ & $6 \times 6$ & $96 \times 78$ \\
\hline & Spacing(cm) & $\begin{array}{l}18 \times 6 \\
\text { Finger millet }\end{array}$ & $\begin{array}{l}60 \times 30 \\
\text { Maize }\end{array}$ & $\begin{array}{l}60 \times 15 \\
\text { Field } \\
\text { lablab }\end{array}$ \\
\hline
\end{tabular}

Fertilizers details:

\begin{tabular}{|c|c|c|c|c|c|c|}
\hline $\begin{array}{c}\text { Crops } \\
\text { varieties }\end{array}$ & \multicolumn{3}{|c|}{ Irrigated (kg ha-1) } & \multicolumn{3}{c|}{ Rainfed (kg ha $\left.{ }^{-1}\right)$} \\
\hline $\begin{array}{c}\text { Finger } \\
\text { millet MR- } \\
\text { 6 }\end{array}$ & 100 & 50 & 50 & 50 & 37.5 & Nitrogen \\
\hline $\begin{array}{c}\text { Field bean } \\
\text { HA-4 }\end{array}$ & 25 & 50 & 25 & 25 & 50 & $\mathbf{2 5}$ \\
\hline $\begin{array}{c}\text { Maize } \\
\text { Nityashree }\end{array}$ & $\mathbf{1 5 0}$ & $\mathbf{7 5}$ & $\mathbf{4 0}$ & $\mathbf{1 0 0}$ & $\mathbf{5 0}$ & $\mathbf{2 5}$ \\
\hline
\end{tabular}




\section{Layout of the experiment}

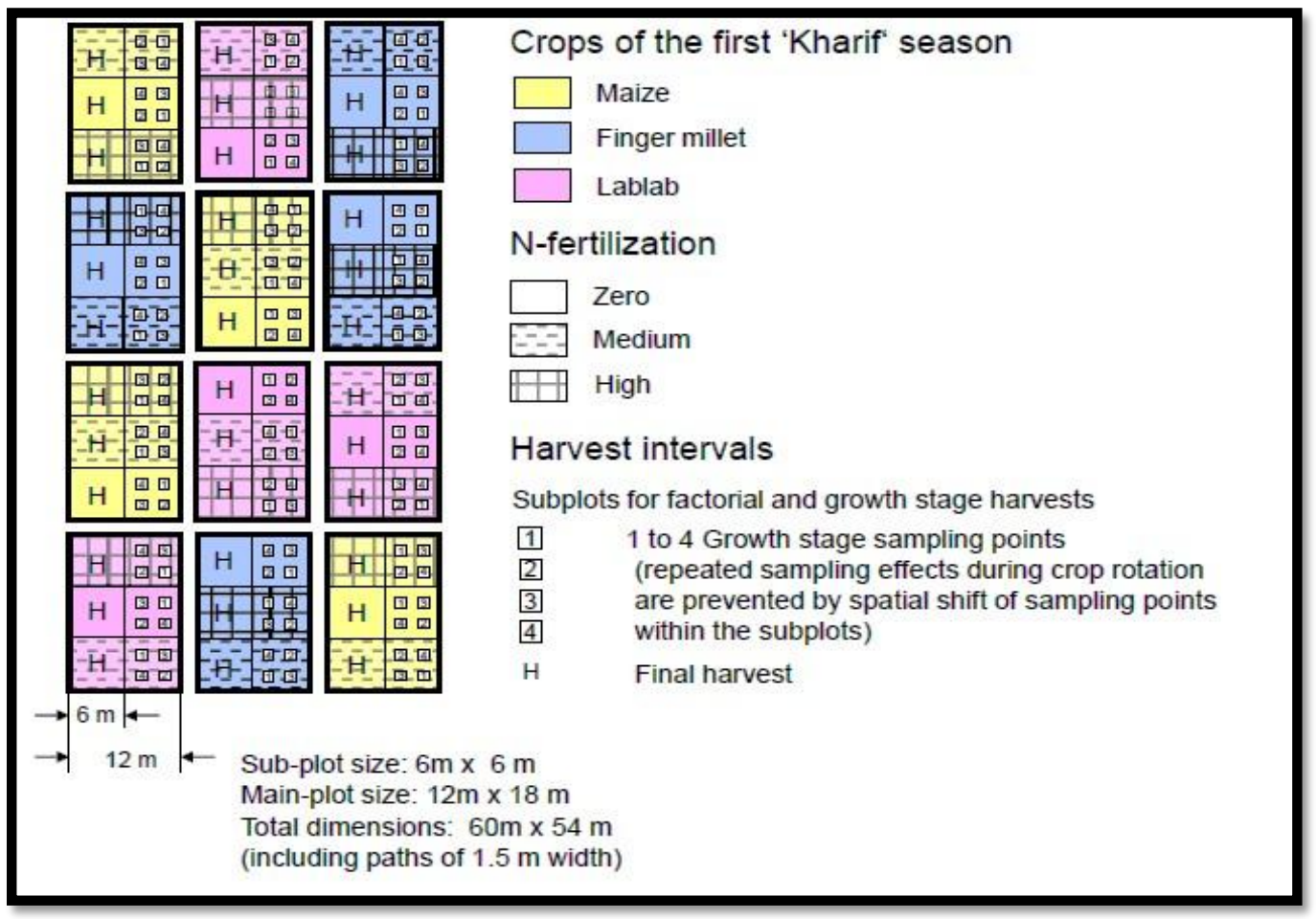

\section{Cultivation of crops}

The crops were cultivated adopting the package of practices in the plots according to the given layout and carried out all the intercultural operation timely. Except the nitrogen all the nutrients were applied at the basal dose and nitrogen was applied in two splits, along $2 / 3$ as basal and rest during tillering stage. The varieties sown are MR-6 for finger millet, HA-4 for field bean, Nityashree for maize. The crops were harvested at optimum stage (plot wise) and the yield were pooled crop wise under different level of nitrogen.

Collection, processing and analysis of soil samples

The soil samples from each of the 36 plots have been collected from $0-15 \mathrm{~cm}$ depth after the harvest of crops and analysed for the soil physico-chemical properties and nutrient status to analyse the effect of different level of nitrogen as well as cropping system on soil nutrient status and soil properties. Initial soil samples were collected before the sowing of crop and analysed basic soil properties

Separation of soil aggregates into macro and micro aggregates

Soil samples have been separated into two different size soil aggregates using wet sieving method. The method used for aggregate-size separation was adapted for the aggregate hierarchy theory over a range of soils from Elliott (1986). Briefly a 100-g subsample (airdried or rewetted) was submerged for 5 min on a $0.25-\mathrm{mm}$ sieve. Aggregates were separated by moving the sieve (by hand) up and down $3 \mathrm{~cm}$ with 50 repetitions during 2 min. The $0.25-\mathrm{mm}$ aggregates were collected. This procedure was repeated for every sample. 
All aggregate fractions were oven-dried and weighed (Yoder, 1936).

Statistical analysis:

The data obtained was subjected to analysis using OPSTAT software with spilt plot analytical method without any transformation. Least square difference was used to compare the treatment effect at $\mathrm{P}<0.05$.

Methodology used to determine available nutrients

\begin{tabular}{|c|c|c|}
\hline Parameter & Method & Reference \\
\hline pH (1:2:Soil:water suspension) & Potentiometric method & Jackson, 1973 \\
\hline $\begin{array}{l}\text { EC (1:2:Soil:water } \\
\text { suspension) }\end{array}$ & Conductometric method & Jackson, 1973 \\
\hline Soil organic Carbon & Wet oxidation method & $\begin{array}{l}\text { Walkey and Black, } \\
1934\end{array}$ \\
\hline Available N & Kjeldahl-distillation & $\begin{array}{l}\text { Subbaiah and } \\
\text { Asija, } 1956\end{array}$ \\
\hline Available $\mathrm{P}_{2} \mathrm{O}_{5}$ & Brays extraction method & Bray and Kurtz. 1945 \\
\hline Available $\mathrm{K}_{2} \mathrm{O}$ & Flame photometry & Jackson, 1973 \\
\hline $\begin{array}{l}\text { DTPA extractable } \\
\text { Micronutrients }\end{array}$ & $\begin{array}{l}\text { Atomic } \\
\text { Absorption } \\
\text { Spectrophotom } \\
\text { eter }\end{array}$ & $\begin{array}{l}\text { Lindsay and } \\
\text { Norvell, } 1978\end{array}$ \\
\hline
\end{tabular}

\section{Results and Discussion}

Initial soil properties

Parameters

$\mathrm{pH}$

$\mathrm{EC}(\mathrm{dSm}-1)$

Available Nitrogen (kg ha-1)

Available Phosphorus $\left(\mathrm{P}_{2} \mathrm{O}_{5}\right)(\mathrm{kg}$ ha-1)

Available potassium (K2O) $\left(\mathrm{kg} \mathrm{ha}^{-1}\right)$

DTPA extracted iron (mg kg-1)

DTPA extracted manganese (mg kg-1)
DTPA extracted zinc (mg kg-1)

1.34

DTPA extracted copper (mg kg-1)

Exchangeable calcium

1.26

(m eq/ 100g soil)

Value Exchangeable magnesium

0.5

$\mathrm{S}$

5.90 Boron (ppm)

0.13

284 Total organic carbon (TOC)

21.66

91.69 The distribution of total organic carbon in two

11.08 different size groups of aggregates, macro and micro, influenced by different levels of 
nitrogen up to the depth of $90 \mathrm{~cm}$ in soil after the harvest of field bean crop, finger millet and maize is presented respectively, in the Table 1, Table 2, and Table 3.

Different levels of nitrogen showed significant impact on distribution of total organic carbon and increase in TOC in soil was observed with increasing levels of nitrogen in all the three crops. Significantly highest mean TOC was observed under $\mathrm{N}_{3}$ level of nitrogen $5.02 \mathrm{~g} \mathrm{~kg}$ 1, $5.44 \mathrm{~g} \mathrm{~kg}^{-1}$ and $5.64 \mathrm{~g} \mathrm{~kg}^{-1}$ under field bean, finger millet and maize cultivated soil, respectively. The lowest was observed under $\mathrm{N}_{1}$ level of nitrogen application with a mean value of $4.01 \mathrm{~g} \mathrm{~kg}^{-1}, 3.98 \mathrm{~g} \mathrm{~kg}^{-1}, 4.88 \mathrm{~g} \mathrm{~kg}^{-1}$ followed by $4.54 \mathrm{~g} \mathrm{~kg}^{-1}, 4.66 \mathrm{~g} \mathrm{~kg}^{-1}, 5.20 \mathrm{~g}^{-1}$ $\mathrm{kg}^{-1}$ under $\mathrm{N}_{2}$ level of nitrogen, respectively in field bean, finger millet and maize cultivated soil irrespective of depth and size of the aggregates. This may be attributed to increased nitrogen application increases the root biomass which add the organic matter and thereof total organic carbon content. As nitrogen is the key element for the soil fertility as well as crop growth which leads to higher production of biomass and hence more return to soil in terms of total organic carbon. Kunduet al. (2002) reported that SOC content improved in fertilized plots as compared to the unfertilized plots was due to $\mathrm{C}$ addition through the roots and crop residues, higher humification rate constant, and lower decay rate (Chatterjee et al., 2018, Saroa and Lal, 2003; Tisdall and Oades, 1982; Bandyopadhyay and Lal, 2015).

Aggregates size affect the distribution of TOC significantly and higher content $\left(4.81 \mathrm{~g} \mathrm{~kg}^{-1}\right)$ was observed under macro aggregates than under micro aggregates $\left(4.24 \mathrm{~g} \mathrm{~kg}^{-1}\right)$ in field bean. Similarly, soil under finger millet and maize cultivation showed significantly higher TOC content under macro aggregates with the value of $5.03 \mathrm{~g} \mathrm{~kg}^{-1}$ and $5.55 \mathrm{~g} \mathrm{~kg}^{-1}$ respectively. In micro aggregates lower content of TOC was noticed with the mean value of $4.52 \mathrm{~g} \mathrm{~kg}^{-1}, 4.93 \mathrm{~g} \mathrm{~kg}^{-1}$ respectively under finger millet and maize cultivation. Among the soils cultivated with different crops, lowest content was observed under field bean. Macro aggregates in all the three crops contained higher total organic carbon content. This might be due to fact that macro aggregates were formed from micro aggregates and organic matter works as one of the binding agent and organic carbon constitutes $58 \%$ of organic matter and hence contributes higher organic carbon content in the same (Park et al., 2007). Six et al. (2000 b) also reported that organic matter acts as one of the binding agent and as per the hierarchical theory of aggregation macro aggregates are formed by coalescing of micro aggregates.

Significant difference of TOC was observed with different depths from $0-15 \mathrm{~cm}$ to $75-90$ $\mathrm{cm}$. The TOC decreased from $6.62 \mathrm{~g} \mathrm{~kg}^{-1}$ to $2.02 \mathrm{~g} \mathrm{~kg}^{-1}$ from surface soil to the depth of $90 \mathrm{~cm}$ in field bean grown soil. Similar trend was followed under finger millet and maize cultivated soil and higher TOC amount was recorded in surface soil samples and declined with increasing depths. The range of TOC with respect to depths deceased from $6.97 \mathrm{~g}$ $\mathrm{kg}^{-1}$ to $2.32 \mathrm{~g} \mathrm{~kg}^{-1}$ and $7.63 \mathrm{~g} \mathrm{~kg}^{-1}$ to $2.55 \mathrm{~g}$ $\mathrm{kg}^{-1}$, respectively for finger millet and maize crop grown soil. Highest mean total organic carbon was obtained at $0-15 \mathrm{~cm}$ depth with a mean value of $6.62 \mathrm{~g} \mathrm{~kg}^{-1}, 6.97 \mathrm{~g} \mathrm{~kg}^{-1}$ and $7.63 \mathrm{~g} \mathrm{~kg}^{-1}$ irrespective of nitrogen level and aggregate sizes in field bean, finger millet and maize cultivated soil, respectively. The declined in the TOC content with increasing depth, might be due to the slow or even negligible leaching of organic carbon up to deeper layers. The addition of organic matter was higher at the surface and which converted to various different forms and undergoes mineralization and even lost as carbon 
dioxide. Thus, very meagre amount of organic carbon reaches to the lower depth and hence the concentration of TOC gradually declined with depth. Similar trend of TOC distribution was documented by Liu et al. (2003).

The interactions of all the three factors i.e, nitrogen levels, aggregates sizes and depths was found as non-significant in field bean, finger millet and maize harvested soil. The effect obtained on the distribution of total organic carbon was solely with the individual factors. Although, the trend showed higher TOC content at $\mathrm{N}_{3}$ level of nitrogen at surface soil $(0-15 \mathrm{~cm})$. The TOC content decreases, with increasing depth and from $\mathrm{N}_{3}$ to $\mathrm{N}_{1}$ levels in the micro aggregates. The TOC content over the nitrogen levels varied with a mean value of 4.01 to $5.02 \mathrm{~g} \mathrm{~kg}^{-1}, 3.98$ to $5.44 \mathrm{~g} \mathrm{~kg}$ ${ }^{-1}$ and 4.88 to $5.64 \mathrm{~g} \mathrm{~kg}^{-1}$ in field bean, finger millet and maize grown soil irrespective of the size of the aggregates and depth. Similarly, macro aggregates were recorded with higher content of TOC with a mean value of 4.28 , 4.48 and $5.24 \mathrm{~g} \mathrm{~kg}^{-1}$, respectively under $\mathrm{N}_{1}$, $\mathrm{N}_{2}$ and $\mathrm{N}_{3}$ levels of nitrogen in field bean, finger millet and maize grown soil irrespective of depth. Thus, the interaction of the three factors with each other was found nonsignificant and effect of individual factor was pronounced.

\section{Available macronutrients}

\section{Available nitrogen}

The available nitrogen content under rainfed experiment was found significantly higher in the plot which receive higher dose of nitrogen $\left(\mathrm{N}_{3}\right)$ fertilizer under field bean cultivation (498.86 kg ha-1) (Table 4). This might be due to the nitrogen fixing ability of the field bean crop which increases the available nitrogen content in the soil. This was followed by same level $\left(\mathrm{N}_{3}\right)$ of nitrogen application under maize cultivated field with value of $416.71 \mathrm{~kg}$ ha- 1 . The lowest for available nitrogen was found with low nitrogen level i.e, no application of nitrogen $\left(\mathrm{N}_{1}\right)$ under finger millet. These results are confirmatory with Mourya (2011) who found linear increase in available nitrogen with increasing the dose of nitrogen fertilizers. The amount of added fertilizers was higher in the maize crop as compared to other two crops and hence imparted higher amount of available nitrogen in the soil. The soil under finger millet at $\mathrm{N}_{1}$ level of nitrogen was recorded with lowest amount of available nitrogen which might be due to no application of fertilizer $(151.01 \mathrm{~kg}$ ha- 1$)$. These results are also supported by the Goshuet al. (2015). However, there was no significant difference observed with the interaction of crop grown and nitrogen levels applied.

\section{Available phosphorus}

Significantly higher amount (61.30 kg ha-1) of available phosphorus was recorded in the $\mathrm{N}_{1}$ treatment under field bean (lablab) cultivation in rainfed experiment (Table 4). The probable reasons may be low rate nitrogen application leads to poor vegetative and root growth which leads to low rate of nutrient absorption from the soil and hence more abundance of phosphorus in it. The lowest amount was observed in $\mathrm{N}_{3}$ treatment with higher dose of nitrogen under maize crop as maize is an exhaustive crop and absorb higher amount of nutrient from the soil leaving lesser content in the soil. Similar results were in the favor of findings of Mourya (2011) who found decrease in the phosphorus availability with increase in nitrogen dosage. Du Preez (1999) and Eludoyin (2011) also found decrease in available phosphorus under corn cultivation due to higher absorption by thecrop. 
Table.1 Effect of different levels of nitrogen on distribution of total organic carbon (TOC) in macro and micro aggregates in field bean under rained condition

\begin{tabular}{|c|c|c|c|c|c|c|c|c|c|c|c|c|c|}
\hline \multicolumn{14}{|c|}{ Total organic carbon (TOC) $\mathrm{g} \mathrm{kg}^{-1}$} \\
\hline \multicolumn{2}{|c|}{ N levels } & \multicolumn{3}{|c|}{$\mathbf{N}_{1}$} & \multicolumn{3}{|c|}{$\mathbf{N}_{2}$} & \multicolumn{3}{|c|}{$\mathbf{N}_{3}$} & \multicolumn{3}{|c|}{ Mean } \\
\hline Depth & A.S & $\begin{array}{l}\text { Ma } \\
\text { cro }\end{array}$ & Micro & $\begin{array}{l}\text { Pooled } \\
\text { Mean } \\
\text { (A) }\end{array}$ & Macro & Micro & $\begin{array}{l}\text { Pooled } \\
\text { Mean } \\
\text { (A) }\end{array}$ & Macro & Micro & $\begin{array}{l}\text { Pooled } \\
\text { Mean } \\
\text { (A) }\end{array}$ & $\begin{array}{c}\text { Macro } \\
\text { (B) }\end{array}$ & $\begin{array}{l}\text { Micro } \\
\text { (B) }\end{array}$ & $\begin{array}{c}\text { Pooled } \\
\text { Mean } \\
\text { (C) }\end{array}$ \\
\hline \multicolumn{2}{|c|}{$0-15$} & 6.07 & 5.40 & 5.74 & 6.98 & 6.19 & 6.59 & 7.92 & 7.13 & 7.53 & 6.99 & 6.24 & 6.62 \\
\hline \multicolumn{2}{|c|}{ 15-30 } & 5.43 & 4.98 & 5.21 & 6.05 & 5.44 & 5.74 & 6.86 & 6.18 & 6.52 & 6.11 & 5.53 & 5.82 \\
\hline \multicolumn{2}{|c|}{$30-45$} & 4.75 & 4.30 & 4.53 & 5.29 & 4.91 & 5.10 & 5.87 & 5.21 & 5.54 & 5.30 & 4.80 & 5.05 \\
\hline \multicolumn{2}{|c|}{$45-60$} & 4.11 & 3.51 & 3.81 & 4.64 & 4.19 & 4.41 & 5.18 & 4.48 & 4.83 & 4.64 & 4.06 & 4.35 \\
\hline \multicolumn{2}{|c|}{$60-75$} & 3.27 & 2.47 & 2.87 & 3.69 & 3.10 & 3.40 & 3.87 & 3.33 & 3.60 & 3.61 & 2.97 & 3.29 \\
\hline \multicolumn{2}{|c|}{$75-90$} & 2.05 & 1.79 & 1.92 & 2.15 & 1.89 & 2.02 & 2.35 & 1.91 & 2.13 & 2.18 & 1.86 & 2.02 \\
\hline \multicolumn{2}{|c|}{$\begin{array}{c}\text { Mean } \\
\text { aggregates }\end{array}$} & 4.28 & 3.74 & 4.01 & 4.80 & 4.29 & 4.54 & 5.34 & 4.71 & 5.02 & 4.81 & 4.24 & \\
\hline \multicolumn{2}{|c|}{ Factors } & \multicolumn{4}{|c|}{ C.D. $(5 \%)$} & \multicolumn{4}{|c|}{ SE(d) } & \multicolumn{4}{|c|}{$\mathrm{SE}(\mathrm{m}) \pm$} \\
\hline \multicolumn{2}{|c|}{ A: N levels } & \multicolumn{4}{|c|}{0.19} & \multicolumn{4}{|c|}{0.10} & \multicolumn{4}{|c|}{0.07} \\
\hline \multicolumn{2}{|c|}{$\begin{array}{l}\text { B: Aggregate } \\
\text { size }\end{array}$} & \multicolumn{4}{|c|}{0.15} & \multicolumn{4}{|c|}{0.08} & \multicolumn{4}{|c|}{0.06} \\
\hline \multicolumn{2}{|c|}{$\mathbf{A X B}$} & \multicolumn{4}{|c|}{$\mathrm{N} / \mathrm{A}$} & \multicolumn{4}{|c|}{0.13} & \multicolumn{4}{|c|}{0.10} \\
\hline \multicolumn{2}{|c|}{ C: Depth } & \multicolumn{4}{|c|}{0.27} & \multicolumn{4}{|c|}{0.13} & \multicolumn{4}{|c|}{0.10} \\
\hline & & & & 0.46 & & & & 23 & & & & & \\
\hline & & & & N/A & & & & 19 & & & & & \\
\hline $\mathbf{A X}$ & $\mathrm{XC}$ & & & $\mathrm{N} / \mathrm{A}$ & & & & 33 & & & & & \\
\hline
\end{tabular}


Table.2 Effect of different levels of nitrogen on distribution of total organic carbon (TOC) in macro and micro aggregates in finger millet under rained condition

\begin{tabular}{|c|c|c|c|c|c|c|c|c|c|c|c|c|c|}
\hline \multicolumn{14}{|c|}{ Total organic carbon (TOC) $\mathrm{g} \mathrm{kg}^{-1}$} \\
\hline \multicolumn{2}{|c|}{ N levels } & \multicolumn{3}{|c|}{$\mathbf{N}_{1}$} & \multicolumn{3}{|c|}{$\mathbf{N}_{2}$} & \multicolumn{3}{|c|}{$\mathbf{N}_{3}$} & \multicolumn{3}{|c|}{ Mean } \\
\hline Depth & A.S & Macro & Micro & $\begin{array}{l}\text { Pooled } \\
\text { Mean } \\
\text { (A) }\end{array}$ & Macro & Micro & $\begin{array}{l}\text { Pooled } \\
\text { Mean } \\
\text { (A) }\end{array}$ & Macro & Micro & $\begin{array}{l}\text { Pooled } \\
\text { Mean } \\
\text { (A) }\end{array}$ & $\begin{array}{c}\text { Macro } \\
\text { (B) }\end{array}$ & $\begin{array}{l}\text { Micro } \\
\text { (B) }\end{array}$ & $\begin{array}{c}\text { Pooled } \\
\text { Mean } \\
\text { (C) }\end{array}$ \\
\hline \multicolumn{2}{|c|}{$0-15$} & 6.63 & 5.88 & 6.26 & 7.33 & 6.44 & 6.89 & 8.18 & 7.34 & 7.76 & 7.38 & 6.55 & 6.97 \\
\hline \multicolumn{2}{|c|}{$15-30$} & 5.60 & 5.22 & 5.41 & 6.30 & 5.84 & 6.07 & 7.42 & 6.80 & 7.11 & 6.44 & 5.95 & 6.20 \\
\hline \multicolumn{2}{|c|}{$30-45$} & 4.79 & 4.23 & 4.51 & 5.25 & 4.87 & 5.06 & 6.73 & 5.97 & 6.35 & 5.59 & 5.02 & 5.31 \\
\hline \multicolumn{2}{|c|}{$45-60$} & 4.42 & 3.78 & 4.10 & 4.77 & 4.23 & 4.50 & 5.47 & 4.91 & 5.19 & 4.89 & 4.31 & 4.60 \\
\hline \multicolumn{2}{|c|}{$60-75$} & 3.07 & 2.80 & 2.93 & 3.41 & 2.81 & 3.11 & 3.66 & 3.82 & 3.74 & 3.38 & 3.14 & 3.26 \\
\hline \multicolumn{2}{|c|}{ 75-90 } & 2.35 & 1.96 & 2.16 & 2.50 & 2.15 & 2.33 & 2.67 & 2.29 & 2.48 & 2.51 & 2.13 & 2.32 \\
\hline \multicolumn{2}{|c|}{$\begin{array}{c}\text { Mean } \\
\text { aggregates }\end{array}$} & 4.48 & 3.98 & 4.23 & 4.93 & 4.39 & 4.66 & 5.69 & 5.19 & 5.44 & 5.03 & 4.52 & \\
\hline \multicolumn{2}{|c|}{ Factors } & \multicolumn{4}{|c|}{ C.D. (5\%) } & \multicolumn{4}{|c|}{ SE(d) } & \multicolumn{4}{|c|}{$\mathrm{SE}(\mathrm{m}) \pm$} \\
\hline \multicolumn{2}{|c|}{ A: N levels } & \multicolumn{4}{|c|}{0.33} & \multicolumn{4}{|c|}{0.17} & \multicolumn{4}{|c|}{0.12} \\
\hline \multicolumn{2}{|c|}{$\begin{array}{c}\text { B: Aggregate } \\
\text { size }\end{array}$} & \multicolumn{4}{|c|}{0.27} & \multicolumn{4}{|c|}{0.14} & \multicolumn{4}{|c|}{0.10} \\
\hline \multicolumn{2}{|c|}{ AXB } & \multicolumn{4}{|c|}{ N/A } & \multicolumn{4}{|c|}{0.23} & \multicolumn{4}{|c|}{0.17} \\
\hline \multicolumn{2}{|c|}{ C: Depth } & \multicolumn{4}{|c|}{0.47} & \multicolumn{4}{|c|}{0.23} & \multicolumn{4}{|c|}{0.17} \\
\hline AX & & & & /A & & & & & & & & & \\
\hline BX & & & & /A & & & & & & & & & \\
\hline $\mathbf{A X B}$ & $\mathbf{X C}$ & & & /A & & & & & & & & & \\
\hline
\end{tabular}


Table.3 Effect of different levels of nitrogen on distribution of total organic carbon (TOC) in macro and micro aggregates in maize under rained condition

\begin{tabular}{|c|c|c|c|c|c|c|c|c|c|c|c|c|c|}
\hline \multicolumn{14}{|c|}{ Total organic carbon (TOC) $\mathrm{g} \mathrm{kg}^{-1}$} \\
\hline \multicolumn{2}{|c|}{ N levels } & \multicolumn{3}{|c|}{$\mathbf{N}_{1}$} & \multicolumn{3}{|c|}{$\mathbf{N}_{2}$} & \multicolumn{3}{|c|}{$\mathbf{N}_{3}$} & \multicolumn{3}{|c|}{ Mean } \\
\hline Depth & A.S & Macro & Micro & $\begin{array}{l}\text { Pooled } \\
\text { Mean } \\
\text { (A) }\end{array}$ & Macro & Micro & $\begin{array}{c}\text { Pooled } \\
\text { Mean } \\
\text { (A) }\end{array}$ & Macro & Micro & $\begin{array}{l}\text { Pooled } \\
\text { Mean } \\
\text { (A) }\end{array}$ & $\begin{array}{c}\text { Macro } \\
\text { (B) }\end{array}$ & $\begin{array}{l}\text { Micro } \\
\text { (B) }\end{array}$ & $\begin{array}{c}\text { Pooled } \\
\text { Mean } \\
\text { (C) }\end{array}$ \\
\hline \multicolumn{2}{|c|}{ 0-15 } & 7.38 & 6.34 & 6.86 & 7.85 & 7.40 & 7.62 & 8.69 & 8.10 & 8.40 & 7.98 & 7.28 & 7.63 \\
\hline \multicolumn{2}{|c|}{$15-30$} & 6.41 & 5.67 & 6.04 & 7.21 & 6.38 & 6.80 & 7.88 & 7.40 & 7.64 & 7.17 & 6.48 & 6.82 \\
\hline \multicolumn{2}{|c|}{$30-45$} & 5.96 & 5.09 & 5.53 & 6.51 & 5.83 & 6.17 & 6.60 & 6.18 & 6.39 & 6.36 & 5.70 & 6.03 \\
\hline \multicolumn{2}{|c|}{$45-60$} & 5.22 & 4.45 & 4.83 & 4.91 & 4.48 & 4.70 & 5.60 & 4.76 & 5.18 & 5.24 & 4.56 & 4.90 \\
\hline \multicolumn{2}{|c|}{$60-75$} & 3.65 & 3.10 & 3.37 & 3.62 & 3.30 & 3.46 & 3.94 & 3.46 & 3.70 & 3.73 & 3.29 & 3.51 \\
\hline \multicolumn{2}{|c|}{ 75-90 } & 2.83 & 2.51 & 2.67 & 2.76 & 2.15 & 2.45 & 2.91 & 2.14 & 2.53 & 2.83 & 2.27 & 2.55 \\
\hline \multicolumn{2}{|c|}{$\begin{array}{c}\text { Mean } \\
\text { aggregates }\end{array}$} & 5.24 & 4.53 & 4.88 & 5.48 & 4.92 & 5.20 & 5.94 & 5.34 & 5.64 & 5.55 & 4.93 & \\
\hline \multicolumn{2}{|c|}{ Factors } & \multicolumn{4}{|c|}{ C.D. $(5 \%)$} & \multicolumn{4}{|c|}{ SE(d) } & \multicolumn{4}{|c|}{$\mathrm{SE}(\mathrm{m}) \pm$} \\
\hline \multicolumn{2}{|c|}{ A: N levels } & \multicolumn{4}{|c|}{0.35} & \multicolumn{4}{|c|}{0.17} & \multicolumn{4}{|c|}{0.12} \\
\hline \multicolumn{2}{|c|}{$\begin{array}{c}\text { B: Aggregate } \\
\text { size }\end{array}$} & \multicolumn{4}{|c|}{0.28} & \multicolumn{4}{|c|}{0.14} & \multicolumn{4}{|c|}{0.10} \\
\hline \multicolumn{2}{|c|}{ AXB } & \multicolumn{4}{|c|}{ N/A } & \multicolumn{4}{|c|}{0.25} & \multicolumn{4}{|c|}{0.17} \\
\hline \multicolumn{2}{|c|}{ C: Depth } & \multicolumn{4}{|c|}{0.49} & \multicolumn{4}{|c|}{0.25} & \multicolumn{4}{|c|}{0.17} \\
\hline AX & & & & /A & & & & 43 & & & & & \\
\hline BX & & & & /A & & & & 35 & & & & & \\
\hline $\mathbf{A X B}$ & $\mathbf{X C}$ & & & /A & & & & 50 & & & & & \\
\hline
\end{tabular}


Table.4 Available NPK status at rainfed experiment

\begin{tabular}{|c|c|c|c|c|}
\hline \multirow{2}{*}{$\begin{array}{l}\text { Parameters } \\
\text { kg ha }^{-1}\end{array}$} & \multirow[t]{2}{*}{ Crops } & \multicolumn{3}{|c|}{ Nitrogen level } \\
\hline & & $\mathrm{N}_{1}$ & $\mathrm{~N}_{2}$ & $\mathbf{N}_{3}$ \\
\hline \multirow{3}{*}{$\begin{array}{c}\text { Available } \\
\text { Nitrogen }\end{array}$} & Field bean & 301.07 & 396.32 & 498.86 \\
\hline & Finger millet & 251.84 & 312.86 & 371.59 \\
\hline & Maize & 271.57 & 389.19 & 416.71 \\
\hline $\mathrm{CD}(\mathrm{p}=0.05)$ & Crops: 54.74 & Nitrogen level:27.42 & \multicolumn{2}{|c|}{ Interaction:NS } \\
\hline \multirow{3}{*}{$\begin{array}{l}\text { Available } \\
\text { Phosphorus }\end{array}$} & Field bean & 61.30 & 51.81 & 41.16 \\
\hline & Finger millet & 42.89 & 35.65 & 28.34 \\
\hline & Maize & \begin{tabular}{|l|l|} 
& 35.14 \\
\end{tabular} & 34.88 & 29.69 \\
\hline $\mathrm{CD}(\mathrm{p}=\mathbf{0 . 0 5})$ & Crops: 6.62 & Nitrogen level: 5.09 & \multicolumn{2}{|c|}{ Interaction:NS } \\
\hline \multirow{3}{*}{$\begin{array}{l}\text { Available } \\
\text { Potassium }\end{array}$} & Field bean & 128.56 & 102.35 & 79.16 \\
\hline & Finger millet & 102.18 & 86.25 & 73.79 \\
\hline & Maize & 153.89 & 112.43 & 94.42 \\
\hline $\mathrm{CD}(\mathrm{p}=0.05)$ & ops:20.70 & Nitrogen level: 22.44 & Interac & \\
\hline
\end{tabular}

A: Crop type; B: Nitrogen level

Table.5 Available micronutrient status at rainfed experiment

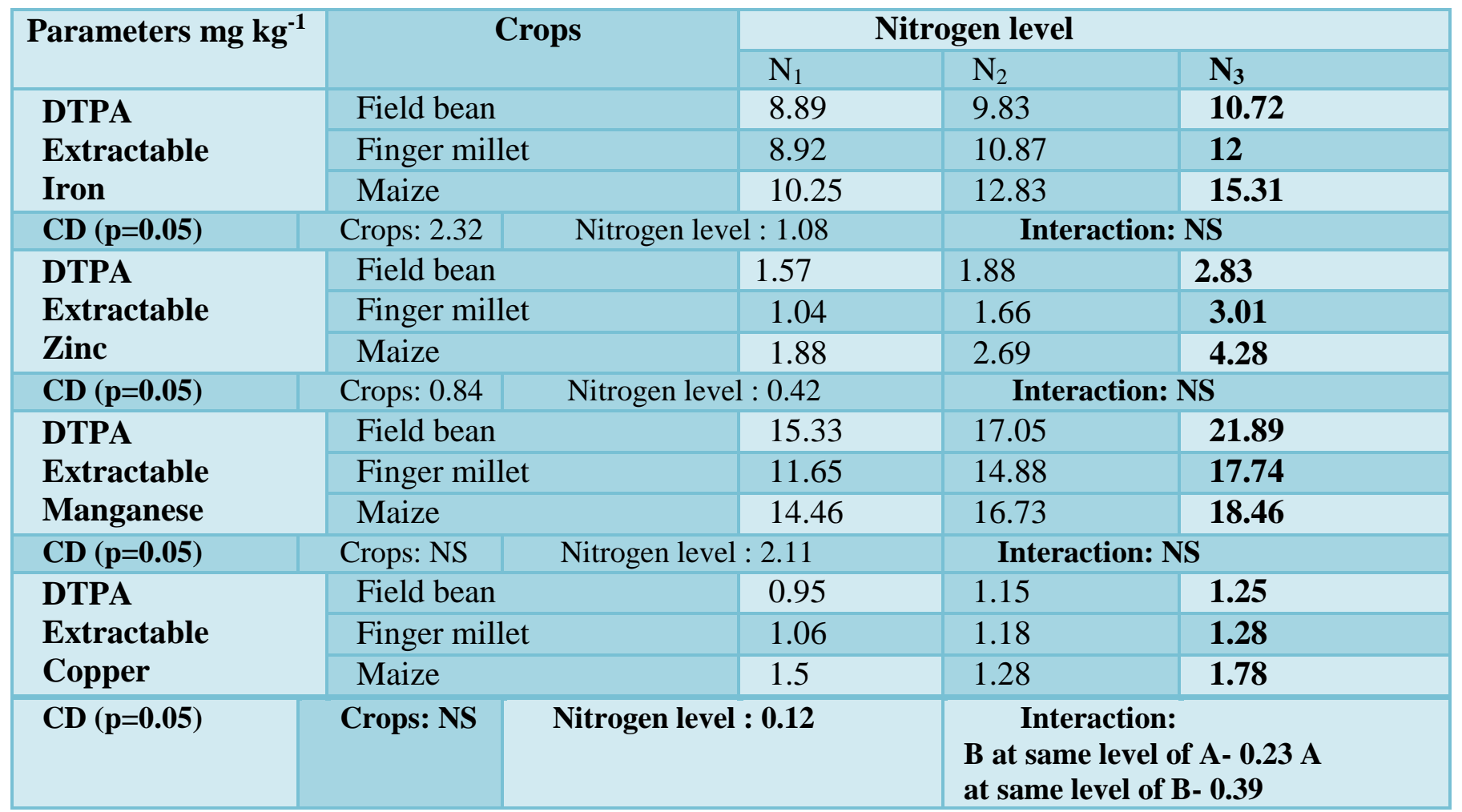

A: Crop type; B: Nitrogen level 


\section{Available potassium}

Available potassium was recorded significantly higher $(153.89 \mathrm{~kg}$ ha-1) in maize crop followed by finger millet plot under $\mathrm{N}_{1}$ low application of nitrogen while lowest amount of $70.39 \mathrm{~kg}$ ha-1 was observed under field bean cultivation with higher nitrogen $\left(\mathrm{N}_{3}\right)$ application in rainfed field experiment (Table 4). This might be due to the similar reason as observed in phosphorus, optimum supply of nitrogen flourished good vegetative growth and which in turn enhances the uptake of nutrient and deplete the available nutrient content in the soil

The lowest amount observed in $\mathrm{N}_{3}$ level of nitrogen may be due to the more uptake of nutrients from the soil under all the crops. These result were in complimentary to Mourya (2011) who also found decrease in potassium with increase in the nitrogen level under French bean.

\section{Available micronutrients}

DTPA extractable iron, manganese, zinc and copper analysed under rainfed experiment recorded significantly higher amount under $\left(\mathrm{N}_{1}\right)$ high dose of nitrogen application irrespective of the crops. However, among the different crops higher content of iron, zinc and copper was observed under maize crop with 15.31, 4.28 and $1.78 \mathrm{Kg}$ ha-1, respectively. DTPA extractable $\mathrm{Mn}$ was found higher under field bean cultivation (21.89 Kg ha-1) at $\mathrm{N}_{3}$ level of nitrogen. Similar, results were obtained by Rangaraj et al. (2007) and Sandhya et al. (2017) who found higher available micronutrients in the treatment which receives higher doses of nitrogen in finger millet crop.

Manganese was reported significantly higher under field bean crop irrespective of dose of nitrogen and reported higher interactive value of $21.89 \mathrm{~kg}$ ha- 1 in $\mathrm{N}_{3}$ level of nitrogen in field bean crop. The lower amount of iron, zinc, manganese and copper micronutrient was observed under $\mathrm{N}_{1}$ level of nitrogen irrespective of crops type grown and lowest value observed was $8.89,1.04,11.65,0.95$ mg kg-1 in case of iron, zinc, manganese and copper (Table no 5). The interaction of crop grown type and level of nitrogen application was found non-significant under both rainfed and irrigated conditions. The higher availability of micronutrients under $\mathrm{N}_{3}$ level of nitrogen was due to the more vegetative growth of the crop due to more application of nitrogen which leads to increase activity of roots and microbes and secretions which may increase the availability of micronutrients.

It is concluded that the present study investigated the effect of different level of nitrogen on the accumulation of total organic carbon under cereal-pulse based cropping system and found out increase in total organic carbon under cultivation of finger millet, maize and field bean with increase in the levels of nitrogen. The macro aggregates accumulated more amount of organic carbon as compared to the micro aggregates. The depth wise distribution showed higher accumulation of TOC at surface soil (0-15 $\mathrm{cm}$ ) due to abundance of organic matter at this layer. The amount of available nutrients was also affected by different levels of nitrogen along with the type of crop cultivated and significantly higher content of available nitrogen and micronutrients were also found significantly higher under high level of nitrogen application under maize crop. The available phosphorus and potassium was recorded in declining trend with increasing the level of nitrogen fertilizers. Among different crop type maize being exhaustive crop was reported with higher mining and lower availability of these nutrients. Field 
bean fixes atmospheric nitrogen and reported with higher content of available nitrogen. However, the interaction effect of nitrogen level and crop grown type was found nonsignificant.

\section{References}

Anonymous, 2010, A fully revised estimates of principle crops in Karnataka for the year of 2007-2008. Direct. Econ. \& Stat., Govt. of Karnataka, pp: 170.

Anonymous, 2010 b, www.indiastat.com.

Bandyopadhyay, K. K. AND LAL, R., 2015, Effect of long-term land use management practices on distribution of $\mathrm{C}$ and $\mathrm{N}$ pools in water stable aggregates in Alfisols. $J$. Indian Soc. Soil Sci., 63(1): 53-63.

Blanco-Canqui H. and Lal L., 2004, Mechanisms of carbon sequestration in soil aggregates. Plant Sci., 23: 481-504.

Chatterjee, S., Bandyopadhyay, K. K., Pradhan, S., Singh, R. and Datta, S. P., 2018,Effects of irrigation, crop residue mulch and nitrogen management in maize (Zea mays L.) on soil carbon pools in a sandy loam soil of Indo-gangetic plain region. Catena, 165: 207-216.

Du Preeza, H.G. and Claassensb, A.S., 1999, Changes in inorganic and organic Phosphorus in soil under maize (Zea mays) cultivation. S Afr J. Plant Soil, (16) 4.

Elliott, E. T., 1986, Aggregate structure and carbon, nitrogen, and phosphorus in native and cultivated soils. Sci. Soc. Am. J., 50: 627-633.

Elliott, E. T. and Coleman, D. C., 1988, Let the soil work for us. Ecol. Bull., 39: 23-32.

Eludoyin, O.S. and Wokocha, C.C. 2011, Soil dynamics under continuous monocropping of maize (Zea mays) on a forest alfisol in south-western Nigeria. Asian J. Agric. Sci. Vol. 3(2), pp 58-62.

Fageria, N.K., Baligar, V.C. and Jones, C.A., 1997, Growth and mineral nutrition of field crops, 2nded.; Marcel Dekker, Inc.: New York.
Jasemi, M., Darabi, F. and Naseri, R., 2013, Effect of planting date andnitrogen fertilizer application on grain yield and yield components in maize (SC 704). AmEurasian. J. Agric. and Environ. Sci.13(7): 914-919.

Kadlec, V., Holubik, O., Prochazkova, E., Urbanova, J., Tippl, M., 2012, Soil organic carbon dynamics and its influence on the soil erodibility factor. Soil Water Res., 7: 97-108.

Khan, M. J., Tareque, A. M. M. and Shajalal, M., 1992, Effect of inoculation and nitrogen fertilizer on yield chemical composition, in vitro organic matter digestibility and energy content of cowpea (Vigna unguiculata) forage. Indian J. Anim. Nutr.9(3): 177-180.

Kharbamon, B., Jha, A.K., Verma, V.K., Choudhury, B.U., Nath, A. and Deka, B.C. 2017, Response of planting time and phosphorus dosage on yield and nutrient uptake indolichos bean (Lablab purpureus L.). Indian J. Hill Farming.30(1): 28-34.

Kundu, S., Prakash, V., Ghosh, B. N., SINGH, R. D. AND SRIVASTVA, A. K., 2002, Quantitative soybean (Glycine max)-wheat (Triticum aestivum) cropping sequence. In: 2nd Int. Agron. Cong., New Delhi, India, November 26-30, pp. 108- 110.

Liu, X.B., Han, X. Z., Herbert, S. J. and Xing, B., 2003, Dynamics of soil organic carbon under different agricultural management systems in the black soil of China. Commun. Soil Sci. Pl. Anal., 34: 973-984.

Monjardino, M., Mcbeath, T.M., Brennan, L. and Llewellyn, R.S., 2013. Are farmers in low rainfall cropping regions under-fertilising with nitrogen? A risk analysis. Agric. Syst. $37-51$.

Monjardino, M., Mcbeath, T., Ouzman, J., Llewellyn, R. and Jones, B., 2015, Farmer risk aversion limits closure of yield and profit gaps: a study of nitrogen management in the southern Australian wheat belt. Agric. Syst. 137, 108-118.

Mourya, B. S., 2011, Effect of nitrogen levels on yield and quality of seed in french bean. Msc thesis, Rajmata Vijayarajesc India Krishi Vishwa Vidyalaya, Gwalior. 
Muhammad. A., Muhammad. T., Muhammad, A. and Abdul, K.,2013, Yield and quality response of forage maize to nitrogen levels and inoculation with PGPRs. Crop and Environ. 4 (1): 35-38.

Park, E. J, Sul, W. J, Ajm, S., 2007, Glucose additions to aggregates subjected to drying/wetting cycles promote carbon sequestration and aggregate stability. Soil Biol. Biochem., 39: 2758-2768.

Rangaraj, T., Somasundaram E., Amanullah, M.M., Thirumurugan, V., Ramesh, S. and Ravi, S., 2007, Effect of agro industrial wastes on soil properties and yield of irrigated finger millet (Eleusine coracana L. Gaertn) in coastal soil. Res.J. Agric. and Biol.Sci.3:153-156.

Sandhya. R. Y., Triveni, U., Patro, TSSK. and Anuradha, N., 2017, Effect of nutrient management on yield and quality of finger millet (Eleusine coracana (L.) Gaertn). Int. J. Chem. Std. 5(6): 1211- 1216.

Sharma, R.B., Jain, V.K. and Verma, S.K., 1988, Influences of different levels of $\mathrm{N}$ on yield and protein of different varieties of finger millet grown under rainfed conditions. Agric. Sci. Digest. 8(3): 161-164.

Saroa, G. S. and Lal, R., 2003, Soil restorative effects of mulching on aggregation and carbon sequestration in a Miamian soil in Central Ohio. Land Degrad. Dev. 14: 481493.

Six, J., Paustian, K., Elliott, E. T. and Combrink, C., 2000 b, Soil Structure and Organic Matter: I. Distribution of Aggregate-Size Classes and Aggregate-Associated Carbon. Soil Sci. Soc. Am. J., 64: 681-689.

Sultana, M. N., Khan, M. J., Khandaker, Z. H. and Uddin, M. M., 2005, Effects of rhizobium inoculums and nitrogen fertilizer on biomass production of cowpea (Vigna unguiculata) forage at different stages of maturity. Bangladesh J. Agri. Univ.3(2): 249-255.

Tisdall, J. M., and Oades, J. M., 1982, Organic matter and water-stable aggregates in soils. J. Soil Sci., 33: 141-163.

Yoder, R. E., 1936, A direct method of aggregate size analysis of soils and a study of the physical nature of erosion losses. J. Am. Soc. Agron., 28: 337-51.

\section{How to cite this article:}

Ushakumari and Sathish, A 2020. Appraisement of Total organic Carbon Under Different Levels of Nitrogen in Different Size Soil Aggregates in Cereal-Pulse Based Cropping System in Rained Condition. Int.J.Curr.Microbiol.App.Sci. 9(01):632-645. doi: https://doi.org/10.20546/ijcmas.2020.901.069 